\title{
Effects of clomazone formulations at the initial development of Jatropha curcas $^{1}$
}

\author{
Luiz Neri Berté2, Neumárcio Vilanova da Costa ${ }^{2}$, João Ricardo Pompermaier Ramella ${ }^{2}$
}

\section{ABSTRACT}

Competition with weeds is one of the obstacles to achieve high yields in jatropha harvest. The chemical method is an alternative weed control due to its high efficiency, readiness and economy, when compared to other methods. However, products recommended for this crop are scarce. This study aimed at evaluating the effects of pre and post-emergence clomazone formulations at the initial development of jatropha. Two experiments were conducted under a randomized blocks design, in a 2 x 5 factorial arrangement, with four replications, consisting of the combination of two clomazone formulations (encapsulated suspension and emulsifiable concentrate) and five doses $\left(0 \mathrm{~g} \mathrm{ha}^{-1}, 250 \mathrm{~g} \mathrm{ha}^{-1}, 500 \mathrm{~g} \mathrm{ha}^{-1}, 1,000 \mathrm{~g} \mathrm{ha}^{-1}\right.$ and 2,000 $\left.\mathrm{g} \mathrm{ha}^{-1}\right)$. The dry matter of the plants was reduced both in the pre-emergence and post-emergence applications. Net photosynthesis was not affected by the application of clomazone in both formulations. The encapsulated suspension formulation is less phytotoxic than the emulsifiable concentrate formulation for pre and post-emergence applications. However, both formulations negatively affect the early development of jatropha plants.

KEY-WORDS: Jatropha curcas; phytotoxicity; weed; inhibitor of carotene.

\section{INTRODUCTION}

The partial or complete replacement of diesel oil by biofuels is a viable and promising alternative for environmental sustainability (Rocha et al. 2010). Jatropha is one of the crops with potential for producing biofuels, due to its high oil content in seeds (33-38\%), long reproductive cycle and high yield (Arruda et al. 2004).

Jatropha (Jatropha curcas L.) is a perennial plant that belongs to the Euphorbiaceae family (Saturnino et al. 2005). Competition with weeds is highlighted among the factors able to affect crop

\section{RESUMO}

Efeitos de formulações de clomazone no desenvolvimento inicial de pinhão-manso

A competição com plantas daninhas é um dos entraves para atingir altas produtividades, na colheita de pinhão-manso. $\mathrm{O}$ método químico é uma alternativa de controle de plantas daninhas, devido à alta eficiência, rapidez e economia, quando comparado aos demais métodos. Porém, há escassez de produtos recomendados para essa cultura. Objetivou-se avaliar os efeitos de formulações de clomazone aplicado em pré e pós-emergência, no desenvolvimento inicial de pinhão-manso. Dois experimentos foram conduzidos sob o delineamento de blocos casualizados, em arranjo fatorial 2 x 5, com 4 repetições, constituindo-se da combinação de duas formulações (suspensão de encapsulado e concentrado emulsionável) e cinco doses de clomazone $\left(0 \mathrm{~g} \mathrm{ha}^{-1}, 250 \mathrm{~g} \mathrm{ha}^{-1}, 500 \mathrm{~g} \mathrm{ha}^{-1}, 1.000 \mathrm{~g} \mathrm{ha}^{-1} \mathrm{e}\right.$ $\left.2.000 \mathrm{~g} \mathrm{ha}^{-1}\right)$. A massa seca das plantas foi reduzida tanto na aplicação em pré-emergência quanto em pós-emergência. A fotossíntese líquida não foi afetada pela aplicação do clomazone em ambas as formulações. A formulação de suspensão de encapsulado é menos fitotóxica do que a de concentrado emulsionável, para as aplicações em pré e pósemergência. Entretanto, ambas as formulações afetam negativamente o desenvolvimento inicial das plantas de pinhão-manso.

PALAVRAS-CHAVE: Jatropha curcas; fitointoxicação; planta daninha; inibidor de caroteno.

yield, since its negative effects are observed from crop implantation until harvest (Saturnino et al. 2005), compromising yield (Erasmo et al. 2009). The chemical method is an interesting alternative for weed control, given its efficiency, speed and low cost, regarding other methods. However, active ingredients and information on herbicide selectivity are still scarce in Brazil (Gonçalvez et al. 2009).

An herbicide formulation must provide active ingredients in adequate concentration, in order to effectively fulfill its biological purpose (Baesso et al. 2014). Emulsifiable concentrates are prepared by diluting the active ingredient, generating a 
concentrated solution. Adjuvants are added to this solution (emulsifiers, stabilizers, correctives, etc.) to enable its mixture with water.

Microencapsulated herbicides have a polymeric layer that isolates the active ingredient and releases it under specific conditions (Bahadir \& Pfister 1990, Seaman 1990). Therefore, the product action becomes more efficient, reducing losses caused by dissolution, degradation and evaporation, thus preventing environmental contamination (Bajpai \& Giri 2002, Kumbar \& Aminabhavi 2002). This technology provides greater handling safety, reduces the total amount of herbicide used and causes less leaching in the soil profile, reducing the impact on biological activities.

The clomazone herbicide is registered for the cassava crop, which belongs to the same family of jatropha (Rodrigues \& Almeida 2005). Thus, it is possible that jatropha plants are also tolerant to this herbicide.

The hypothesis of this study is that the clomazone selectivity depends on the herbicide formulation, dose and application mode. Accordingly, it aimed at evaluating the effects of pre and postemergence clomazone formulations at the initial development of jatropha plants.

\section{MATERIAL AND METHODS}

Two experiments were carried out in a greenhouse to evaluate the pre and post-emergence clomazone selectivity in jatropha plants. A randomized blocks design, in a 2 x 5 factorial arrangement, with 4 replications, was used. Treatments consisted of a combination of two clomazone formulations (encapsulated suspension and emulsifiable concentrate) and five doses $\left(0 \mathrm{~g} \mathrm{ha}^{-1}, 250 \mathrm{~g} \mathrm{ha}^{-1}\right.$, $500 \mathrm{~g} \mathrm{ha}^{-1}, 1,000 \mathrm{~g} \mathrm{ha}^{-1}$ and 2,000 $\mathrm{g} \mathrm{ha}^{-1}$ ).

For sowing and transplanting, a deep and clayey eutroferric red Oxisol (Embrapa 2006) was used. The soil was collected in an agricultural area, sieved ( $5 \mathrm{~mm}$ mesh) and distributed in pots (capacity of about $18 \mathrm{dm}^{3}$ of soil).

The soil analysis (0.0-0.20 $\mathrm{m}$ depth) presented the following characteristics: $\mathrm{pH}\left(\mathrm{CaCl}_{2}\right)=5.5$; organic matter $=6.84 \mathrm{~g} \mathrm{dm}^{-3} ; \mathrm{P}=1.75 \mathrm{mg} \mathrm{dm}^{-3}$; $\mathrm{H}+\mathrm{Al}=3.73 \mathrm{cmol}_{\mathrm{c}} \mathrm{dm}^{-3} ; \mathrm{K}=0.15 \mathrm{cmol}_{\mathrm{c}} \mathrm{dm}^{-3} ; \mathrm{Mg}=$ $0.91 \mathrm{cmol}_{\mathrm{c}} \mathrm{dm}^{-3} ; \mathrm{Ca}=4.79 \mathrm{cmol}_{\mathrm{c}} \mathrm{dm}^{-3}$, sum of bases $=$ $5.85 \mathrm{cmol}_{\mathrm{c}}^{\mathrm{c}} \mathrm{dm}^{-3}$; and CEC $=9.58 \mathrm{cmol}_{\mathrm{c}} \mathrm{dm}^{-3}$. Therefore, liming was not necessary and fertilization was carried out in a balanced way, based on recommendations for castor beans (Ricinus communis) (Scivittaro \&
Pillon 2006), due to the nonexistence of a specific fertilization recommendation for jatropha.

For pre-emergence treatments, sowing was carried out on January 18th 2012, at a density of 3 seeds pot ${ }^{-1}$. Then, plants were thinned out, preserving the most vigorous one. Post-emergence treatments took place immediately after sowing.

For the post-emergence treatments, seedlings were prepared in properly standardized tubes and transplanted to the pots at 63 days after sowing (DAS). Treatments were applied at 29 days after transplanting (DAT). For the treatments application, a tunnel with plastic canvas and $2.0 \mathrm{~m}$ high poles was built, where pots were spaced along one-meter lines, $0.5 \mathrm{~m}$ apart, simulating a real field spatial distribution. A knapsack sprayer with Jacto ${ }^{\circledR}$ F110/0$8 / 3(110 / \mathrm{LD} / 02)$ nozzles, pressurized with $\mathrm{CO}_{2}$ and equipped with a bar with four nozzles spaced $0.5 \mathrm{~m}$ apart (pressure of $45 \mathrm{Lb} \mathrm{in}^{-2}$ and spray volume of $200 \mathrm{~L} \mathrm{ha}^{-1}$ ), was used in the applications.

Phytotoxicity symptoms, total dry matter and net photosynthesis were evaluated in both assays.

Phytotoxicity symptoms were evaluated at $13,22,29,37,42,50$ and 56 days after application (DAA) in the pre-emergence assay, and at 7, 13, 22, 29, 37 and 42 DAA in the post-emergence assay. Phytotoxicity was visually assessed, following a percentage grading scale, where 0 corresponds to no intoxication and 100 to plant death (SBCPD 1995).

Plant total dry matter (g) was evaluated by collecting the plants, which were stored in paper bags and then dried in a forced ventilation oven at $65^{\circ} \mathrm{C}$, until reaching constant mass.

Net photosynthesis was determined in the morning (from 9 to 11 a.m.), on sunny days, on leaves located at the middle third of plants. Leaves had to be fully developed, with no injuries. The net photosynthesis reading was carried out in two different leaves, for each plant of the pot, using an IRGA LI-6400XT (Licor Inc. Lincoln, NE). Preemergence application was evaluated at 24, 29, 42, and 51 DAA and post-emergence application at 14 , 24, 29 and 42 DAA.

Phytotoxicity symptoms, total dry matter content and gas exchange were evaluated using analysis of variance ( $F$ test; $p<0.05$ ) and, when significant differences were detected, a regression analysis was used. Significance and the highest coefficient of determination $\left(\mathrm{R}^{2}\right)$ were considered to choose the model. A minimum significance level 
of $5 \%$ was considered for all the tests, using the SigmaPlot 12.0 software.

\section{RESULTS AND DISCUSSION}

For the encapsulated suspension formulation (Figure 1a), the maximum phytotoxicity values $(60 \%)$ were recorded at 25 and $35 \mathrm{DAA}$, for the $2,000 \mathrm{~g} \mathrm{ha}^{-1}$ dose. The release of the microcapsule contents to the medium occurs gradually through

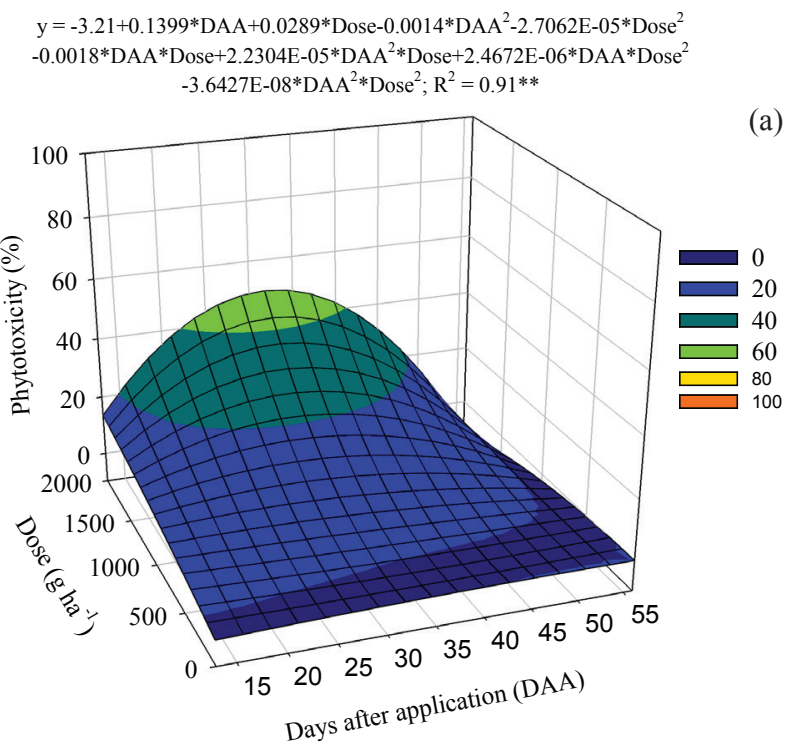

$\mathrm{y}=9.3814-1.0394 *$ DAA-0.054*Dose $+0.0162 *$ DAA $^{2}-4.2325 \mathrm{E}-07 *$ Dose $^{2}$ $+0.006 *$ DAA $^{*}$ Dose-9.5231 E- $05 *$ DAA $^{2} *$ Dose-1.1476E- $07 *$ DAA $^{*}$ Dose $^{2}$ $+3.9567 \mathrm{E}-09 * \mathrm{DAA}^{2} *$ Dose $^{2} ; \mathrm{R}^{2}=0.86 * *$

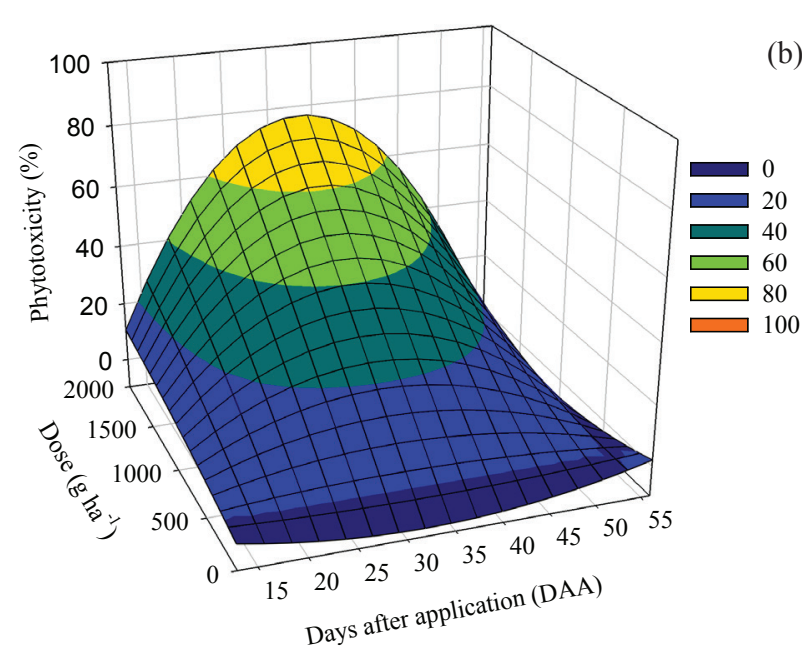

Figure 1. Phytotoxicity of jatropha plants up to 55 days after the application (DAA) of pre-emergence clomazone formulations (Marechal Cândido Rondon, Paraná State, Brazil, 2013). a) Encapsulated suspension at $360 \mathrm{~g} \mathrm{~L}^{-1}$; b) emulsifiable concentrate at $500 \mathrm{~g} \mathrm{~L}^{-1}$. mechanical disruption, caused by temperature, $\mathrm{pH}$, solubility, biodegradation and diffusion (Whorton 1995). The slow release of the active principle is the probable cause of the lower phytotoxicity observed with the encapsulated suspension.

When the emulsifiable concentrate formulation was used (Figure $1 \mathrm{~b}$ ), the maximum phytotoxicity values $(80 \%)$ were observed at 30 and 35 DAA, respectively for the $1,000 \mathrm{~g} \mathrm{ha}^{-1}$ and 2,000 $\mathrm{g} \mathrm{ha}^{-1}$ doses. The jatropha plants began to recover from the phytotoxicity symptoms caused by both herbicide formulations from 35 DAA. As expected, the increase of both pre-emergence clomazone formulation doses also increases phytotoxicity symptoms (Figure 1). The herbicide selectivity to a crop is associated with product related factors, crop morphology and physiology and application methods (Oliveira Júnior 2001).

Dry matter accumulation was reduced by $14.8 \%, 24.9 \%, 35.9 \%$ and $44.6 \%$, when used the $250 \mathrm{~g} \mathrm{ha}^{-1}, 500 \mathrm{~g} \mathrm{ha}^{-1}, 1,000 \mathrm{~g} \mathrm{ha}^{-1}$ and $2,000 \mathrm{~g} \mathrm{ha}^{-1}$ doses for the encapsulated suspension formulation, respectively, regarding the control. For the emulsifiable concentrate formulation, reductions of $12.2 \%, 12.9 \%, 38.3 \%$ and $79.1 \%$ were observed at the $250 \mathrm{~g} \mathrm{ha}^{-1}, 500 \mathrm{~g} \mathrm{ha}^{-1}, 1,000 \mathrm{~g} \mathrm{ha}^{-1}$ and 2,000 $\mathrm{g} \mathrm{ha}^{-1}$ doses, respectively, regarding the control (Figure 2).

These results show that selectivity may not be determined only by visual symptoms, since, despite

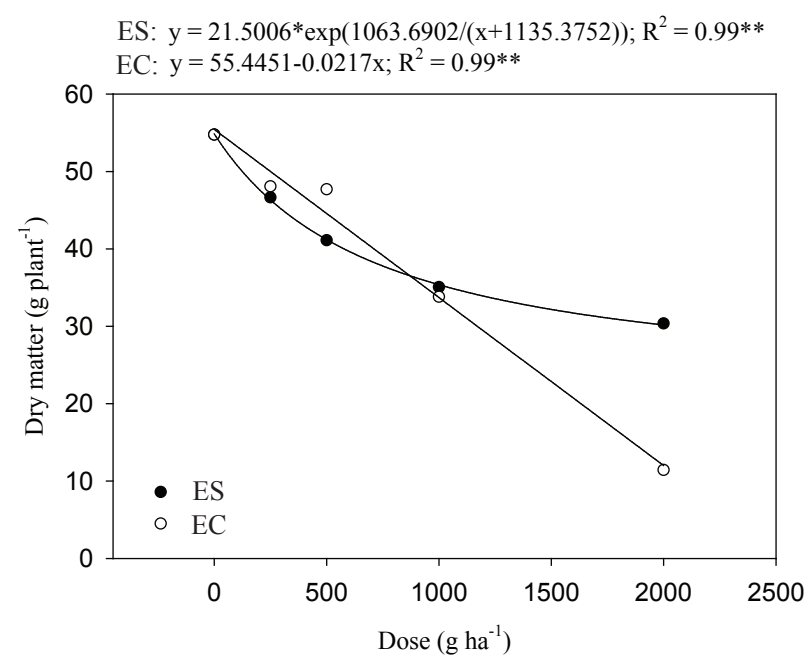

Figure 2. Total dry matter of jatropha plants at 56 days after the application (DAA) of pre-emergence clomazone formulations (Marechal Cândido Rondon, Paraná State, Brazil, 2013). • Encapsulated suspension (ES) at $360 \mathrm{~g} \mathrm{~L}^{-1}$; o emulsifiable concentrate (EC) at $500 \mathrm{~g} \mathrm{~L}^{-1}$. 
the recovery from the phytotoxicity symptoms after 35 DAA, a significant reduction in total dry matter was observed. The damage caused by herbicides are more prominent on plant growth than on visual phytotoxicity symptoms, which may reduce the dry matter content of plants (Galon et al. 2009).

The net photosynthesis of the jatropha leaves from 24 to 51 DAA was not influenced by the pre-emergence clomazone application for both the formulations tested (Figure 3).
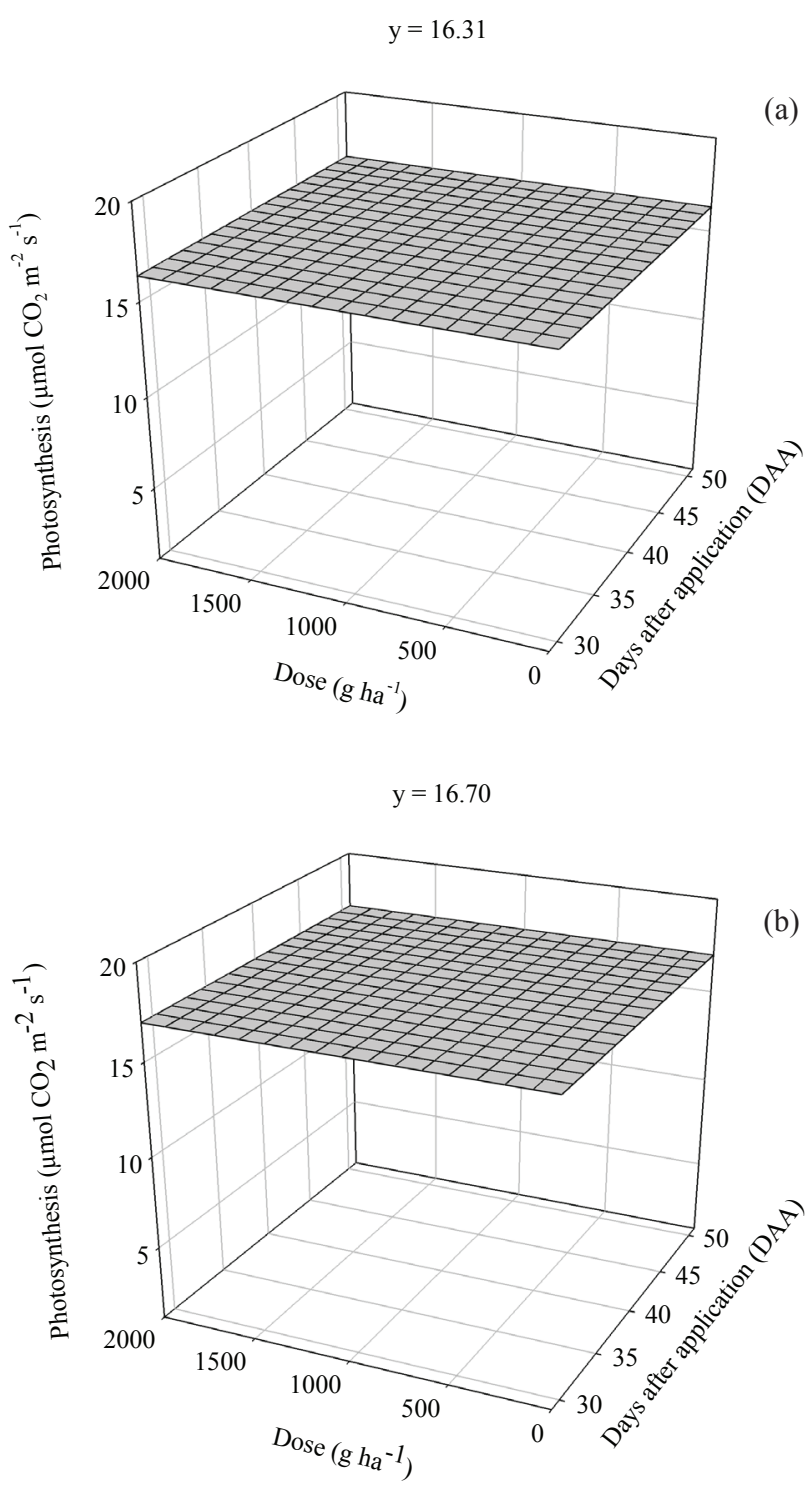

Figure 3. Net photosynthesis of jatropha plants at 24 days after the application (DAA) of the two formulations and five pre-emergence clomazone doses (Marechal Cândido Rondon, Paraná State, Brazil, 2013). a) Encapsulated suspension at $360 \mathrm{~g} \mathrm{~L}^{-1}$; b) emulsifiable concentrate at $500 \mathrm{~g} \mathrm{~L}^{-1}$.
Data on phytotoxicity of jatropha plants up to 42 DAA of post-emergence clomazone formulations are shown in Figure 4.

Forboth formulations, the maximum phytotoxicity values were lower than $40 \%$, for the $1,000 \mathrm{~g} \mathrm{ha}^{-1}$ and $2,000 \mathrm{~g} \mathrm{ha}^{-1}$ doses. The symptoms were observed up to 15 DAA for the encapsulated suspension formulation (Figure 4a), while the maximum phytotoxicity values for the emulsifiable concentrate formulation were recorded from 10 to 30 DAA (Figure $4 b$ ).
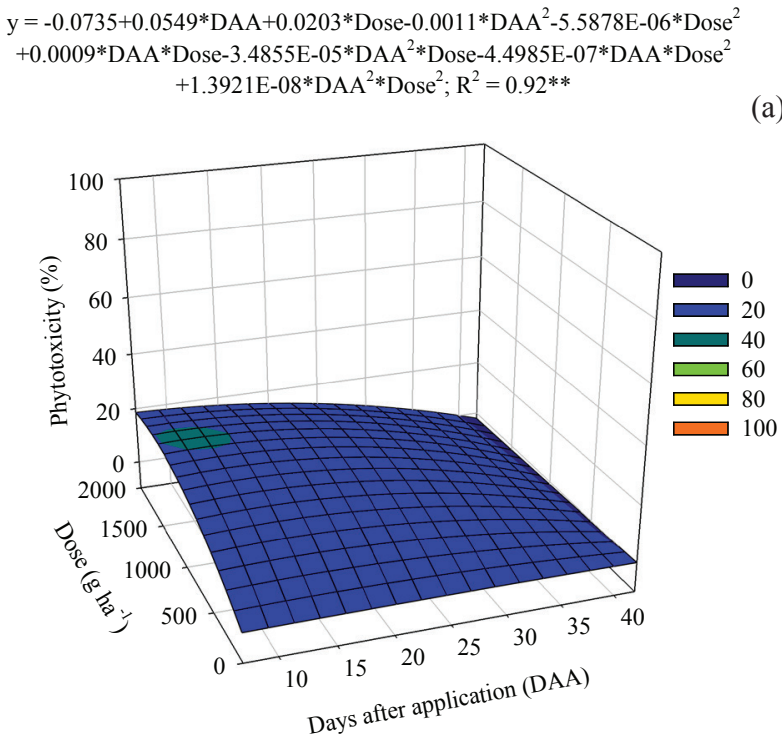

$\mathrm{y}=0.379-0.0224 * \mathrm{DAA}+0.0109 *$ Dose $+3.6003 \mathrm{E}-05 * \mathrm{DAA}^{2}-4.3211 \mathrm{E}-06 * \mathrm{Dose}^{2}$ $+0.0013 *$ DAA $^{*}$ Dose-3.7677E-05*DAA ${ }^{2} *$ Dose-1.82965E-07*DAA*Dose ${ }^{2}$ $+7.0209 \mathrm{E}-09 * \mathrm{DAA}^{2} * \mathrm{Dose}^{2} ; \mathrm{R}^{2}=0.97 * *$

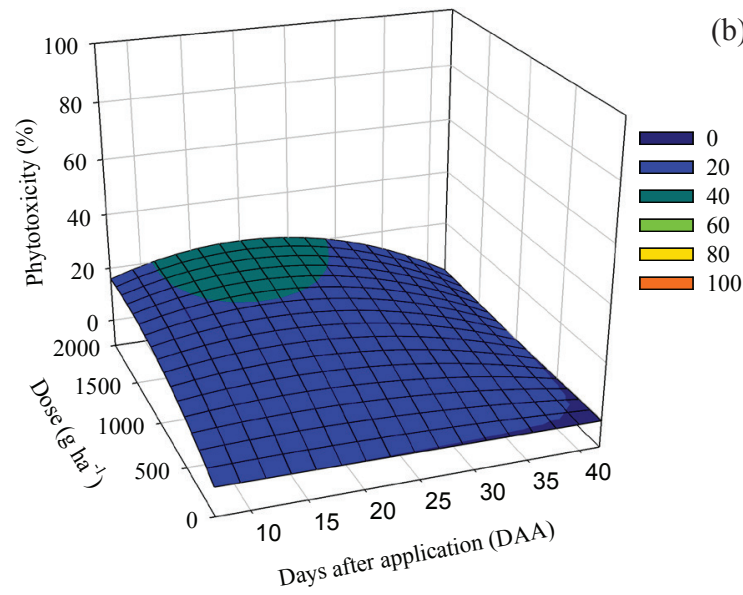

Figure 4. Phytotoxicity of jatropha plants up to 42 days after the application (DAA) of the two formulations and five post-emergence clomazone doses (Marechal Cândido Rondon, Paraná State, Brazil, 2013). a) Encapsulated suspension at $360 \mathrm{~g} \mathrm{~L}^{-1}$; b) emulsifiable concentrate at $500 \mathrm{~g} \mathrm{~L}^{-1}$. 
The dry matter accumulation was reduced in both formulations, following the increase in the postemergence clomazone dose (Figure 5). However, this reduction occurred with a lower intensity for both formulations, when compared to the pre-emergence application (Figure 2).

The net photosynthetic rates showed an increase for all doses of the encapsulated suspension formulation up to 42 DAA (Figure 6a). When the emulsifiable concentrate formulation was used, an increase in the net photosynthesis was observed for all doses up to 35 DAA, with a subsequent reduction from 36 to 42 DAA.

The aforementioned results differ from those observed for the pre-emergence applications, due to the form of clomazone application. In the postemergence application, the spray reaches the plants directly, while in the pre-emergence one the seed is protected by a soil layer, reducing the absorption of the active ingredient during the germination process, with less damage to photosynthesis.

For post-emergence applications, as the plant starts to recover from the maximum peak of phytotoxicity caused by the herbicide, new leaves are emitted and may present the highest photosynthetic potential, as well as increase the source/drain relation with senescent leaves (Dellai et al. 2008).

The lowest net photosynthesis rates observed in the first assessment (14 DAA; Figures 6a and 6b)

$E S: y=72.6902+37.4991 * \exp (-0.0031 * x) ; R^{2}=0.99 * *$ EC: $y=113.0993-0.0195 * x ; R^{2}=0.70 *$

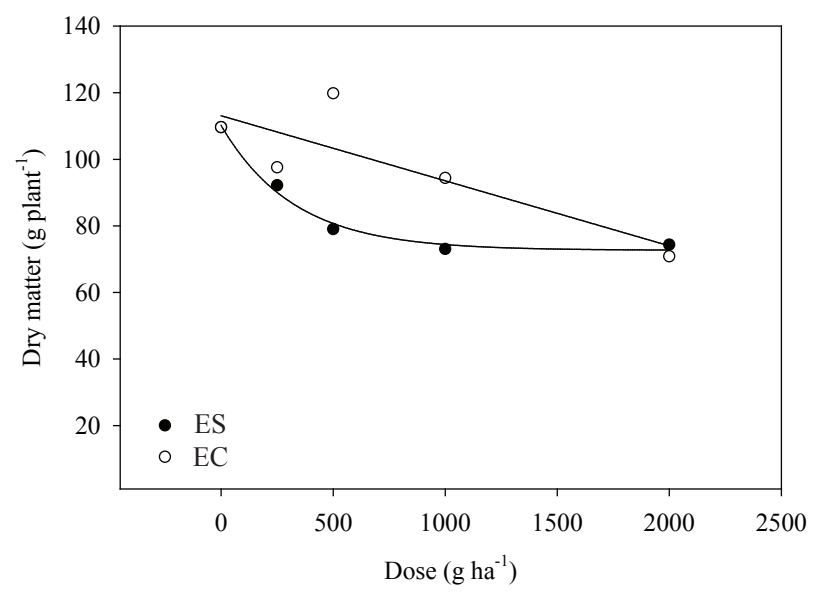

Figure 5. Total dry matter of jatropha plants at 42 days after the application (DAA) of post-emergence clomazone formulation (Marechal Cândido Rondon, Paraná State, Brazil, 2013). • Encapsulated suspension (ES) at $360 \mathrm{~g} \mathrm{~L}^{-1}$; o emulsifiable concentrate (EC) at $500 \mathrm{~g} \mathrm{~L}^{-1}$. followed the same pattern observed for phytotoxicity (Figures $4 \mathrm{a}$ and $4 \mathrm{~b}$ ), which presented the highest percentage in the same period.

The pre-emergence clomazone application in the encapsulated suspension formulation (900 $\mathrm{g} \mathrm{ha}^{-1}$ and 1,080 $\mathrm{g} \mathrm{ha}^{-1}$ ) were selective for the 'cascuda' cassava cultivar, which also belongs to the Euphorbiaceae family (Scariot et al. 2013). Similarly, the post-emergence clomazone application after pruning in the 'baianinha' cassava crop caused lower phytotoxicity when using the encapsulated suspension formulation than when using the emulsifiable concentrate, at $900 \mathrm{~g} \mathrm{ha}^{-1}$ doses (Costa
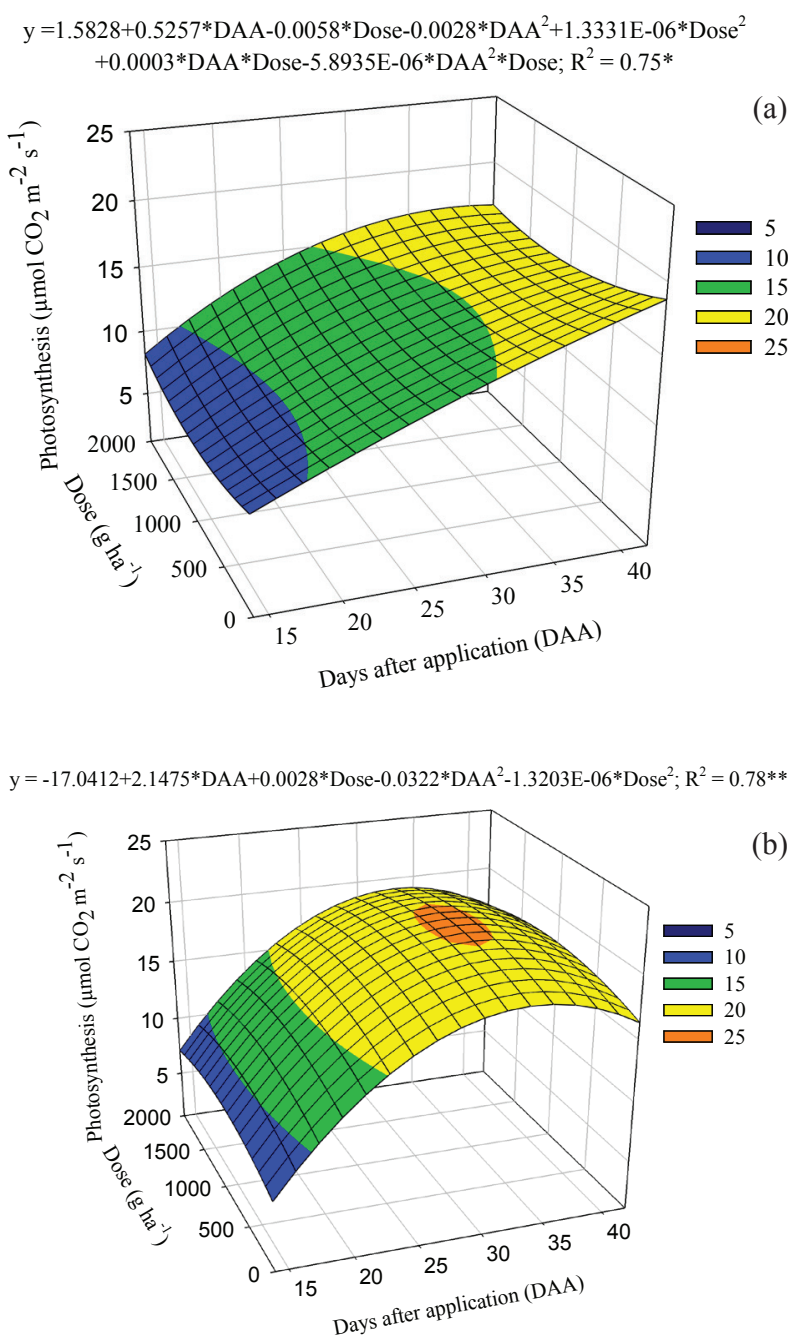

Figure 6. Net photosynthesis of jatropha plants at 14 days after the application (DAA) of the two clomazone formulations and five post-emergence doses (Marechal Cândido Rondon, Paraná State, Brazil, 2013). a) Encapsulated suspension at $360 \mathrm{~g} \mathrm{~L}^{-1}$; b) emulsifiable concentrate at $500 \mathrm{~g} \mathrm{~L}^{-1}$. 
et al. 2013). However, these authors consider both formulations selective for the cassava crop.

The results presented do not confirm the hypothesis of this study, which predicts that the clomazone herbicide registered for the cassava crop could also be selective for jatropha plants.

Further studies exploring other molecules to determine herbicides selective to jatropha are necessary, due to the lack of information on selective herbicides in the literature and assessments considering field conditions.

\section{CONCLUSION}

For pre and post-emergence applications, the encapsulated suspension clomazone formulation is less phytotoxic than the emulsifiable concentrate formulation. However, both formulations negatively affect the initial development of jatropha plants.

\section{REFERENCES}

ARRUDA, F. P. et al. Cultivo de pinhão-manso (Jatropha curcas L.) como alternativa para o semiárido nordestino. Revista Brasileira de Oleaginosas e Fibrosas, Campina Grande, v. 8, n. 1, p. 789-799, 2004.

BAESSO, M. M. et al. Pesticide application technologies. Ceres, Viçosa, v. 61, supl., p. 780-785, 2014.

BAHADIR, M.; PFISTER, G. Controlled release formulations of pesticides. In: HAUG, G. et al. (Eds.). Controlled release, biochemical effects of pesticides, inhibition of plant pathogenic fungi. Berlin: SpringerVerlag, 1990. p. 1-64.

BAJPAI, A. K.; GIRI, A. Swelling dynamics of a ternary interpenetrating polymer network (IPN) and controlled release of potassium nitrate as a model agrochemical. Journal of Macromolecular Science, Washington, DC, v. 39, n. 1-2, p. 75-102, 2002.

COSTA, N. V. et al. Selectivity of clomazone and S-metolachlor applied after cassava pruning. Planta Daninha, Viçosa, v. 31, n. 4, p. 979-985, 2013.

DELLAI, J. et al. Densidade de plantio na produção hidropônica de minitubérculos de batata. Ciência Rural, Santa Maria, v. 38, n. 6, p. 1534-1539, 2008.

EMPRESA BRASILEIRA DE PESQUISA AGROPECUÁRIA (Embrapa). Centro Nacional de Pesquisa de Solos. Sistema brasileiro de classificação de solos. 2. ed. Rio de Janeiro: Embrapa, 2006.
ERASMO, E. A. L. et al. Tolerância inicial de plantas de pinhão-manso a herbicidas aplicados em pré e pósemergência. Planta Daninha, Viçosa, v. 27, n. 3, p. 571$580,2009$.

GALON, L. et al. Seletividade de herbicidas a genótipos de cana-de-açúcar. Planta Daninha, Viçosa, v. 27, n. esp., p. 1083-1093, 2009.

GONÇALVES, K. S.; SÃO JOSÉ, A. R.; VELINI, E. D. Seletividade do oxyfluorfen para a cultura do pinhãomanso. Planta Daninha, Viçosa, v. 27, n. esp., p. 11111116, 2009.

KUMBAR, S. G.; AMINABHAVI, T. M. Preparation and characterization of interpenetrating network beads of poly (vinyl alcohol)-grafted-poly (acrylamide) with sodium alginate and their controlled release characteristics for cypermethrin pesticide. Journal of Applied Polymer Science, Hoboken, v. 84, n. 3, p. 552-560, 2002.

OLIVEIRA JÚNIOR, R. S. Seletividade de herbicidas e plantas daninhas. In: OLIVEIRA JÚNIOR, R. S.; CONSTANTIN, J. Plantas daninhas e seu manejo. Guaíba: Agropecuária, 2001. p. 291-313.

ROCHA, P. R. R. et al. Seletividade de herbicidas préemergentes ao pinhão-manso (Jatropha curcas). Planta daninha, Viçosa, v. 28, n. 4, p. 801-806, 2010.

RODRIGUES, B. N.; ALMEIDA, F. S. Guia de herbicidas. Londrina: Ed. dos autores, 2005.

SATURNINO, H. M. et al. Cultura do pinhão-manso (Jatropha curcas L.). Informe Agropecuário, Belo Horizonte, v. 26, n. 1, p. 44-78, 2005.

SCARIOT, C. A. et al. Seletividade e eficiência de herbicidas aplicados em pré-emergência na cultura da mandioca. Pesquisa Agropecuária Tropical, Goiânia, v. 43, n. 3, p. 300-307, 2013.

SCIVITTARO, W. B.; PILLON, C. N. Adubação e calagem para a cultura da mamona no Sul do Brasil. Pelotas: Embrapa Clima Temperado, 2006. (Boletim técnico, 150).

SEAMAN, D. Trends in the formulation of pesticides: an overview. Pesticide Science, Malden, v. 29, n. 4, p. 437449, 1990.

SOCIEDADE BRASILEIRA DA CIÊNCIA DAS PLANTAS DANINHAS (SBCPD). Procedimentos para instalação, avaliação e análise de experimentos com herbicidas. Londrina: SBCPD, 1995.

WHORTON, C. Factors influencing volatile release from encapsulation matrices. Washington, DC: ACS, 1995. 